\title{
DETEKSI KEMUNDURAN BENIH KEDELAI (Glycine max L.) DENGAN METODE PENGUSANGAN CEPAT (Accelerated Aging Test) KIMIAWI
}

\section{SEED DETERIORATION DETECTION OF SOYBEAN (Glycine max L.) WITH CHEMICAL ACCELERATED AGING TEST}

\author{
Ria Putri ${ }^{*}$, Ari Wahyuni ${ }^{1}$, Riana Jumawati ${ }^{2}$ \\ ${ }^{1}$ Program Studi Teknologi Perbenihan, Jurusan Budidaya Tanaman Pangan, Politeknik Negeri Lampung, Indonesia \\ ${ }^{2}$ Program Studi Hortikultura, Jurusan Budidaya Tanaman Pangan, Politeknik Negeri Lampung, Indonesia \\ *Email: riaputri@polinela.ac.id
}

*Corresponding Author, Diterima: 28 Des 2020, Direvisi: 11 Feb. 2021, Disetujui: 29 Apr. 2021

\begin{abstract}
The deterioration of seeds occurs due to a decrease in the physiological quality of the seeds during the storage period. This study aimed to determine the effect of the intensity of chemical accelerated aging on the viability and vigor of two soybean varieties. This research was conducted from January to April 2021 in the seed analysis laboratory and greenhouse of Seed Technology Study Program, Lampung State Polytechnic. This study used a completely randomized design with two factors and four replications. The first factor was the soybean variety which consists of two levels, namely Dega $\left(V_{1}\right)$ and Deja $\left(V_{2}\right)$. The second factor was accelerated aging (the immersion time of $20 \%$ ethanol) which consists of five levels, namely 0 minutes $\left(T_{0}\right), 15$ minutes $\left(T_{1}\right), 30$ minutes $\left(T_{2}\right), 45$ minutes $\left(T_{3}\right)$, and 60 minutes $\left(T_{4}\right)$. The results of this study indicated that (1) the intensity of the 0 to 60 minute accelerated aging decreased the viability as indicated by the decrease in the percentage of field emergence (2) the viability and vigor of Deja is higher than Dega based on the percentage of field emergence, the number of leaves, primary root length and rate of assimilation of soybean, and (3) Deja had higher resistance to 20\% ethanol compared to Dega as indicated by the Deja seeds still growth at 60 minutes of accelerated aging.
\end{abstract}

Keywords: Accelerated aging test, seed deterioration, seed viability, soybean.

\begin{abstract}
ABSTRAK
Kemunduran benih terjadi karena penurunan mutu fisiologi benih selama periode simpan. Penelitian ini bertujuan untuk mengetahui pengaruh intensitas pengusangan cepat kimiawi pada viabilitas dan vigor benih dua varietas kedelai. Penelitian ini dilaksanakan dari bulan Januari sampai April 2021 di laboratorium analisis benih dan greenhouse Program Studi Teknologi Perbenihan, Politeknik Negeri Lampung. Penelitian menggunakan Rancangan Acak Lengkap (RAK) dengan dua faktor dan empat ulangan. Faktor pertama adalah varietas kedelai yang terdiri atas dua taraf yaitu varietas Dega $\left(\mathrm{V}_{1}\right)$ dan varietas Deja $\left(\mathrm{V}_{2}\right)$. Faktor kedua adalah waktu pengusangan (perendaman cairan etanol 20\%) yang terdiri atas lima taraf yaitu 0 menit $\left(\mathrm{T}_{0}\right), 15$ menit $\left(\mathrm{T}_{1}\right), 30$ menit $\left(\mathrm{T}_{2}\right), 45$ menit $\left(\mathrm{T}_{3}\right)$, dan 60 menit $\left(\mathrm{T}_{4}\right)$. Hasil penelitian dapat disimpulkan bahwa (1) intensitas waktu pengusangan 0-60 menit menurunkaan viabilitas yang ditunjukkan dengan menurunnya persentase daya tumbuh benih (2) viabilitas dan vigor benih varietas Deja lebih tinggi dibandingkan dengan varietas Dega pada peubah persentase daya tumbuh, jumlah daun, panjang akar primer dan laju asimilasi kecambah kedelai, dan (3) varietas Deja memiliki
\end{abstract}


ketahanan lebih tinggi terhadap deraan etanol 20\% dibandingkan dengan varietas Dega yang ditunjukkan dengan masih tumbuhnya benih varietas Deja pada waktu pengusangan 60 menit.

Kata kunci : Metode pengusangan cepat, kedelai, kemunduran benih, viabilitas benih.

\section{PENDAHULUAN}

Kedelai merupakan salah satu bahan pangan pokok masyarakat Indonesia. Kedelai banyak diminati karena mengandung protein nabati sebagai bahan baku olahan makanan seperti tempe, tahu, tepung, dan kecap. Permintaan kedelai terus meningkat dari tahun ke tahun, tetapi tidak diikuti dengan peningkatan produksi. Oleh karena itu, untuk memenuhi kebutuhan kedelai yang tinggi diperlukan impor (Manurung, 2002). Data dari Badan Pusat Statistik (2020) menunjukkan bahwa pada tahun 2019 impor kedelai Indonesia mencapai 2.670.086,4 ton. Pemerintah hingga saat ini terus berupaya untuk meningkatkan produksi kedelai agar dapat menekan impor. Salah satu upaya yang dapat dilakukan adalah dengan penggunaan benih bermutu. Penggunaan benih bermutu merupakan salah satu kunci keberhasilan dalam budidaya tanaman. Benih yang bermutu memiliki sifat fisiologi, fisik dan genetik yang baik yang dipengaruhi oleh proses produksi sampai penyimpanan (Sadjad, 1980).

Penyediaan benih kedelai yang bermutu memiliki kendala yaitu daya simpan benih yang pendek terutama jika disimpan pada ruang terbuka atau open storage. Kemunduran benih dapat terjadi selama periode simpan. Menurut Justice and Bass (2002) menyatakan bahwa laju kemunduran benih dipengaruhi oleh genetik, dormansi benih, ketebalan, dan struktur kulit serta komposisi benih, sehingga laju kemunduran benih berbeda untuk setiap benih. Kandungan lemak (16\%) dan protein (37\%) pada benih kedelai yang relatif tinggi dan kondisi lingkungan yang lembab menyebabkan kemunduran benih terjadi secara cepat (Tatipata, 2008).

Kemunduran benih dapat dilakukan dengan metode pengusangan cepat. Metode pengusangan cepat dapat dilakukan untuk mengetahui perbedaan vigor benih pada varietas yang berbeda (Ozouline, et al., 2009). Metode pengusangan cepat dapat dilakukan secara fisik maupun kimia. Pengusangan cepat secara kimia dapat dilakukan dengan menggunakan larutan etanol, uap etanol jenuh maupun larutan metanol. (Addai, dan Kantanka., 2006) melakukan perendaman benih kedelai dalam $20 \%$ cairan etanol dan $20 \%$ cairan metanol selama dua jam dan dapat menyimpulkan bahwa perendaman dalam cairan etanol memberikan indikasi yang lebih baik pada vigor daya simpan beberapa varietas kedelai dibandingkan dalam cairan metanol.

Benih diperlakukan pada kondisi tidak ideal yaitu didera sesuai dengan kondisi simpan yang sebenarnya seperti suhu dan kelembaban udara tinggi, sehingga terjadi devigorasi benih yang dapat menyebabkan penurunan viabilitas benih secara buatan (Mustika, et al., 2014). Penelitian ini bertujuan untuk mengetahui pengaruh intensitas pengusangan cepat kimiawi pada viabilitas dan vigor benih dua varietas kedelai. 


\section{BAHAN DAN METODE}

Penelitian ini dilaksanakan dari bulan Januari sampai April 2021 di laboratorium analisis benih dan greenhouse Program studi Teknologi Perbenihan, Jurusan Budidaya Tanaman Pangan, Politeknik Negeri Lampung. Bahan yang digunakan dalam penelitian meliputi dua lot benih kedelai yang diperoleh dari Balitkabi yaitu varietas Dega dan varietas Deja etanol $20 \%$, air aquades, kain streamine, kantong plastik, media tanam, label dan kertas stensil. Alat yang digunakan dalam penelitian ini adalah tray, penggaris, peralatan analisis laju asimilasi ( $\mathrm{Li}$-6800 Portable Photosynthesis System), gelas kimia dan gelas ukur.

Penelitian ini menggunakan Rancangan Acak Lengkap (RAK) dengan dua faktor dan empat ulangan. Faktor pertama adalah varietas kedelai yang terdiri atas dua taraf yaitu varietas Dega $\left(\mathrm{V}_{1}\right)$ dan varietas Deja $\left(\mathrm{V}_{2}\right)$ dengan viabilitas awal masing-masing varietas adalah $90.67 \%$ dan $92 \%$. Faktor kedua adalah waktu perendaman cairan etanol $20 \%$ yang terdiri atas lima taraf yaitu 0 menit $\left(\mathrm{T}_{0}\right), 15$ menit $\left(\mathrm{T}_{1}\right), 30$ menit $\left(\mathrm{T}_{2}\right)$, 45 menit $\left(\mathrm{T}_{3}\right)$, dan 60 menit $\left(\mathrm{T}_{4}\right)$.

Penelitian diawali dengan meningkatkan kadar air benih, setiap ulangan sebanyak $25 \mathrm{~g}$ benih. Peningkatan kadar air dilakukan dengan melembabkan benih pada kertas CD yang lembab selama 12 jam di dalam refrigerator suhu $5^{\circ} \mathrm{C}$ sehingga kadar air meningkat menjadi $\pm 30 \%$ secara merata. Benih yang telah mengalami peningkatan kadar air secara merata selanjutnnya dikembalikan untuk menyesuaikan diri pada suhu ruang dan mengaktifkan proses metabolismenya. Benih kemudian direndam ke dalam larutan etanol 20\% sesuai dengan lama perendaman yang digunakan yaitu $0,15,30,45$, dan 60 menit.

Setiap varietas benih kedelai dihitung sebagai satu percobaan. Benih kedelai sebanyak 100 butir dikemas dalam kain streamine yang berukuran $10 \mathrm{~cm}$ x $10 \mathrm{~cm}$. Selanjutnya, benih direndam dalam toples kaca (berukuran $500 \mathrm{~mL}$ ) yang telah berisi larutan etanol $20 \%$ sebanyak $200 \mathrm{~mL}$ untuk 100 butir benih. Setiap perlakuan diulang sebanyak empat kali dan setiap satuan percobaan terdiri atas 25 butir. Benih yang telah direndam kemudian ditiriskan lalu dikecambahkan di dalam tray dengan media tanam tanah, sekam bakar, dan pupuk kendang dengan perbandingan 1:1:1. Variabel pengamatan terdiri atas: persentase daya tumbuh (\%), tinggi tanaman $(\mathrm{cm})$, jumlah daun (helai), panjang akar $(\mathrm{cm})$, dan laju asimilasi $\left(\operatorname{mol} \mathrm{m}\left\{{ }^{2} \mathrm{~s}\left\{{ }^{1}\right)\right.\right.$ yang diukur saat tanaman berumur 21 hari setelah benih diusangkan selama $0,15,30,45$, dan 60 menit.

Data hasil pengamatan diuji homogenitasnya dengan uji Bartlett dan ketidakaditifan data dengan uji Tukey kemudian dianalisis dengan sidik ragam dan dilanjutkan dengan uji Beda Nyata Terkecil (BNT) pada taraf $5 \%$.

\section{HASIL DAN PEMBAHASAN}

Hasil penelitian menunjukkan bahwa varietas kedelai yang digunakan berpengaruh sangat nyata terhadap persentase daya tumbuh, panjang akar dan laju asimilasi, tetapi varietas tidak mempengaruhi jumlah daun dan tinggi tanaman kedelai. Waktu pengusangan benih dengan etanol $20 \%$ berpengaruh sangat nyata pada semua variabel pengamatan yaitu persentase daya tumbuh, jumlah daun, tinggi tanaman, panjang akar dan 
laju asimilasi. Interaksi antara varietas dan waktu pengusangan benih kedelai menunjukkan pengaruh yang sangat nyata terhadap jumlah daun dan tinggi tanaman dan interaksi nyata terhadap panjang akar dan laju asimilasi. Akan tetapi, interaksi antara varietas dan waktu pengusangan tidak mempengaruhi persentase daya tumbuh (Tabel 1).

Data pada Tabel 2 menampilkan persentase daya tumbuh dua varietas kedelai yang digunakan. Data ini menunjukkan bahwa persentase daya tumbuh varietas Deja paling tinggi yaitu sebesar $37.20 \%$ dibandingkan dengan persentase daya tumbuh varietas Dega yaitu sebaesar $28.60 \%$. Hal ini menunjukkan bahwa varietas Deja lebih baik dibandingkan dengan varietas Dega.

Persentase daya tumbuh kedelai pada waktu pengusangan 0 menit atau tanpa diusangkan menunjukkan hasil yang paling tinggi yaitu $88.50 \%$. Waktu pengusangan 15 dan 30 menit tidak menunjukkan perbedaan yang signifikan terhadap persentase daya tumbuh kedelai. Persentase daya tumbuh terendah terlihat pada waktu pengusangan 60 menit yaitu sebesar 3.5\% (Tabel 3). Hal ini menunjukkan bahwa semakin lama waktu pengusangan yang diaplikasikan, maka persentase daya tumbuh tanaman akan semakin menurun. Penurunan persentase daya tumbuh terbebut disebabkan oleh kemunduran benih kedelai. Kemunduran benih karena pengusangan merupakan simulasi penyimpanan benih. Semakin lama waktu pengusangan mensimulasikan waktu penyimpanan benih yang lebih lama. Hal ini sejalan dengan penelitian (Nizaruddin, et al., 2013) yang menyatakan bahwa lama pengusangan menggambarkan periode simpan benih kedelai. Selain itu, hasil penelitian Rosida, et al. (2015) menunjukkan bahwa perendaman benih kubis dalam etanol $20 \%$ selama 30

Tabel 2. Persentase daya tumbuh dua varietas kedelai

\begin{tabular}{lc}
\hline Varietas & Daya Tumbuh $(\%)$ \\
\hline Dega $\left(\mathrm{V}_{1}\right)$ & $28.60 \mathrm{~b}$ \\
Deja $\left(\mathrm{V}_{2}\right)$ & $37.20 \mathrm{a}$ \\
\hline \multicolumn{2}{l}{ Keterangan: Dua nilai tengah diikuti huruf yang sama tidak } \\
& berbeda berdasarkan uji BNT pada taraf $5 \%$.
\end{tabular}

Tabel 3. Persentase daya tumbuh kedelai pada waktu

\begin{tabular}{cc}
\hline $\begin{array}{c}\text { Waktu Pengusangan } \\
(\text { menit })\end{array}$ & Daya Tumbuh $(\%)$ \\
\hline $0\left(\mathrm{~T}_{0}\right)$ & $88.50 \mathrm{a}$ \\
$15\left(\mathrm{~T}_{1}\right)$ & $28.00 \mathrm{~b}$ \\
$30\left(\mathrm{~T}_{2}\right)$ & $27.50 \mathrm{~b}$ \\
$45\left(\mathrm{~T}_{3}\right)$ & $17.00 \mathrm{c}$ \\
$60\left(\mathrm{~T}_{4}\right)$ & $3.50 \mathrm{~d}$ \\
\hline
\end{tabular}

$\overline{\text { Keterangan: Dua nilai tengah diikuti huruf yang sama tidak }}$ berbeda berdasarkan uji BNT pada taraf $5 \%$.

Tabel 1. Rekapitulasi analisis sidik ragam pengaruh varietas kedelai dan waktu pengusangan benih pada vigor kecambah

\begin{tabular}{|c|c|c|c|c|c|}
\hline Sumber Keragaman & $\begin{array}{l}\text { Persentase daya } \\
\text { tumbuh }(\%)\end{array}$ & $\begin{array}{c}\text { Jumlah } \\
\text { daun (helai) }\end{array}$ & $\begin{array}{c}\text { Tinggi } \\
\text { tanaman }(\mathrm{cm})\end{array}$ & $\begin{array}{l}\text { Panjang akar } \\
\text { (cm) }\end{array}$ & $\begin{array}{l}\text { Laju Asimilasi } \\
\left(\mathrm{mol} \mathrm{m} ?^{2} \mathrm{~s} ?^{1}\right)\end{array}$ \\
\hline Varietas (V) & $* *$ & $\operatorname{tn}$ & th & $* *$ & $* *$ \\
\hline Waktu Pengusangan (T) & $* *$ & $* *$ & $* *$ & $* *$ & $* *$ \\
\hline Interaksi $\mathrm{VxT}$ & $\operatorname{tn}$ & $* *$ & $* *$ & $*$ & $*$ \\
\hline
\end{tabular}

Keterangan: $* *=$ Sangat Berbeda pada $\alpha 1 \%, *=$ Berbeda pada $\alpha 5 \%$, tn $=$ Tidak Berbeda pada $\alpha 5 \%$ 
menit berkorelasi dengan daya kecambah benih setelah disimpan selama enam bulan pada suhu ruang simpan terbuka $\left(23.3-29.9{ }^{\circ} \mathrm{C}\right)$.

Benihyangmengalami waktupengusangan lebih lama akan mengalami respirasi yang terjadi terus menerus. Menurut Afriansyah, et al. (2021), jika proses respirasi benih terjadi terus menerus, maka proses perombakan cadangan makanan akan semakin banyak. Hal ini dapat mengakibatkan cadangan makanan benih habis, sehingga saat benih ditanam tidak dapat berkecambah. Selain itu, menurut Anggraeni, et al.(2014) menyatakan bahwa etanol yang diserap benih saat pengusangan dapat mendenaturasi protein yang ada di dalam benih. Jika fungsi protein struktural terganggu maka akan mengakibatkan kebocoran membran. Kebocoran membran dapat menyebabkan banyak metabolit yang keluar, sehingga substrat untuk respirasi berkurang dan energi yang dihasilkan untuk berkecambah juga berkurang (Titipata et al., 2004).

Pengaruh varietas kedelai dan waktu pengusangan terhadap jumlah daun ditampilkan pada Tabel 4. Interaksi antara varietas dan waktu pengusangan berpengaruh terhadap jumlah daun. Pada waku pengusangan 15,30, dan 45 menit varietas Dega menunjukkan jumlah daun yang lebih banyak dibandingkan varietas Deja. Varietas Dega pada waktu pengusangan 60 menit sudah tidak mampu tumbuh, akan tetapi varietas Deja masih dapat tumbuh dan menghasilkan jumlah daun sebesar 2.25 helai.

Interkasi sangat nyata antara varietas dan waktu pengusangan terhadap tinggi tanaman ditampilkan pada tabel 5. Hasil ini menunjukkan bahwa varietas Dega

Tabel 4. Interaksi antara varietas dan waktu pengusangan pada variabel jumlah daun

\begin{tabular}{lccccc}
\hline \multirow{2}{*}{ Varietas } & \multicolumn{5}{c}{ Waktu Pengusangan (menit) } \\
\cline { 2 - 6 } & $0\left(\mathrm{~T}_{0}\right)$ & $15\left(\mathrm{~T}_{1}\right)$ & $30\left(\mathrm{~T}_{2}\right)$ & $45\left(\mathrm{~T}_{3}\right)$ & $60\left(\mathrm{~T}_{4}\right)$ \\
\hline \multirow{2}{*}{$\operatorname{Dega}\left(\mathrm{V}_{1}\right)$} & $2.25 \mathrm{a}$ & $3.00 \mathrm{a}$ & $2.75 \mathrm{a}$ & $2.50 \mathrm{a}$ & $0.00 \mathrm{~b}$ \\
& $(\mathrm{c})$ & $(\mathrm{a})$ & $(\mathrm{ab})$ & $(\mathrm{bc})$ & $(\mathrm{d})$ \\
\multirow{2}{*}{$\operatorname{Deja}\left(\mathrm{V}_{2}\right)$} & $2.00 \mathrm{a}$ & $2.00 \mathrm{~b}$ & $2.00 \mathrm{~b}$ & $2.00 \mathrm{~b}$ & $2.25 \mathrm{a}$ \\
& $(\mathrm{a})$ & $(\mathrm{a})$ & $(\mathrm{a})$ & $(\mathrm{a})$ & $(\mathrm{a})$ \\
\hline
\end{tabular}

Keterangan: Nilai tengah diikuti huruf yang sama tidak berbeda berdasarkan uji BNT pada taraf 5\%. Huruf dalam kurung dibaca arah horizontal, membandingkan antara Waktu Pengusangan pada varietas yang sama. Huruf kecil tanpa kurung dibaca arah vertikal, membandingkan antara varietas pada waktu pengusangan yang sama.

Tabel 5. Interaksi varietas dan waktu pengusangan pada variabel tinggi tanaman

\begin{tabular}{cccccc}
\hline \multirow{2}{*}{ Varietas } & $0\left(\mathrm{~T}_{0}\right)$ & $15\left(\mathrm{~T}_{1}\right)$ & $30\left(\mathrm{~T}_{2}\right)$ & $45\left(\mathrm{~T}_{3}\right)$ & $60\left(\mathrm{~T}_{4}\right)$ \\
\cline { 2 - 6 } $\operatorname{Dega}\left(\mathrm{V}_{1}\right)$ & $12.96 \mathrm{a}$ & $14.16 \mathrm{a}$ & $14.69 \mathrm{a}$ & $13.74 \mathrm{a}$ & $0.00 \mathrm{~b}$ \\
& $(\mathrm{a})$ & $(\mathrm{a})$ & $(\mathrm{a})$ & $(\mathrm{a})$ & $(\mathrm{b})$ \\
$\operatorname{Deja}\left(\mathrm{V}_{2}\right)$ & $10.66 \mathrm{a}$ & $10.92 \mathrm{~b}$ & $10.94 \mathrm{~b}$ & $11.13 \mathrm{~b}$ & $8.94 \mathrm{a}$ \\
& $(\mathrm{a})$ & $(\mathrm{a})$ & $(\mathrm{a})$ & $(\mathrm{a})$ & $(\mathrm{a})$ \\
\hline $\begin{array}{l}\text { Keterangan: Nilai tengah diikuti huruf yang sama tidak berbeda berdasarkan uji BNT pada taraf 5\%. Huruf dalam kurung dibaca arah } \\
\text { horizontal, membandingkan antara Waktu Pengusangan pada varietas yang sama. Huruf kecil tanpa kurung dibaca arah } \\
\text { vertikal, membandingkan antara varietas pada waktu pengusangan yang sama. }\end{array}$
\end{tabular}


dan Deja pada waktu pengusangan 0 menit tidak berbeda nyata. Pada waktu pengusangan 15,30 , dan 45 menit varietas Dega memiliki tinggi tanaman yang lebih tinggi dibandingkan varietas Deja. Akan tetapi, varietas Deja masih mampu tumbuh pada waktu pengusangan 60 menit dan memiliki tinggi tanaman sebesar $8.94 \mathrm{~cm}$.

Meskipun jumlah daun dan tinggi tanaman varietas Dega lebih tinggi dibandingkan varietas Deja pada waktu pengusangan 15, 30, dan 45 menit. Akan tetapi, varietas Deja masih mampu bertahan pada waktu pengusangan 60 menit. Hal ini mengindikasikan bahwa varietas Deja dapat disimpan lebih lama dibandingkan dengan varietas Dega. Artinya, varietas Deja mampu menekan laju kemunduran benih meskipun memiliki jumlah daun dan tinggi tanaman yang lebih rendah dibandingkan varietas Dega. Menurut Copeland, dan Mc Donald, (2001) salah satu faktor yang mempengaruhi kemunduran benih adalah genetik benih. Hasil ini menunjukkan bahwa varietas Deja secara genetik diduga mampu menghemat energi dalam perombakan cadanganmakanan setelah didera etanol $20 \%$.

Interaksi antara varietas dan waktu pengusangan terhadap panjang akar dapat dilihat pada Tabel 6. Hasil ini menunjukkan bahawa varietas Dega pada waktu pengusangan 45 menit memiliki panjang akar yang lebih panjang yaitu $17.13 \mathrm{~cm}$ dibandingkan dengan varietas Dega yaitu $8.68 \mathrm{~cm}$. Selain itu, varietas Deja pada waktu pengusangan 60 menit masih mampu tumbuh dan menghasilkan pajang akar primer sebesar $11.83 \mathrm{~cm}$, sedangkan varietas Dega sudah tidak mampu tumbuh. Hal ini mengindikasikan bahwa benih varietas

Tabel 6. Interaksi varietas dan waktu pengusangan pada variabel panjang akar primer

\begin{tabular}{lccccc}
\hline \multirow{2}{*}{ Varietas } & \multicolumn{5}{c}{ Waktu Pengusangan (menit) } \\
\cline { 2 - 6 } & $0\left(\mathrm{~T}_{0}\right)$ & $15\left(\mathrm{~T}_{1}\right)$ & $30\left(\mathrm{~T}_{2}\right)$ & $45\left(\mathrm{~T}_{3}\right)$ & $60\left(\mathrm{~T}_{4}\right)$ \\
\hline \multirow{2}{*}{ Dega $\left(\mathrm{V}_{1}\right)$} & $12.41 \mathrm{a}$ & $14.11 \mathrm{a}$ & $15.52 \mathrm{a}$ & $8.68 \mathrm{~b}$ & $0.00 \mathrm{~b}$ \\
& $(\mathrm{ab})$ & $(\mathrm{ab})$ & $(\mathrm{a})$ & $(\mathrm{b})$ & $(\mathrm{c})$ \\
\multirow{2}{*}{ Deja $\left(\mathrm{V}_{2}\right)$} & $14.67 \mathrm{a}$ & $16.96 \mathrm{a}$ & $16.09 \mathrm{a}$ & $17.13 \mathrm{a}$ & $11.83 \mathrm{a}$ \\
& $(\mathrm{a})$ & $(\mathrm{a})$ & $(\mathrm{a})$ & $(\mathrm{a})$ & $(\mathrm{a})$ \\
\hline
\end{tabular}

Keterangan: Nilai tengah diikuti huruf yang sama tidak berbeda berdasarkan uji BNT pada taraf 5\%. Huruf dalam kurung dibaca arah horizontal, membandingkan antara Waktu Pengusangan pada varietas yang sama. Huruf kecil tanpa kurung dibaca arah vertikal, membandingkan antara varietas pada waktu pengusangan yang sama.

Tabel 7. Interaksi varietas dan waktu pengusangan pada variabel laju asimilasi kecambah benih

\begin{tabular}{lccccc}
\hline \multirow{2}{*}{ Varietas } & \multicolumn{5}{c}{ Waktu Pengusangan (menit) } \\
\cline { 2 - 6 } & $0\left(\mathrm{~T}_{0}\right)$ & $15\left(\mathrm{~T}_{1}\right)$ & $30\left(\mathrm{~T}_{2}\right)$ & $45\left(\mathrm{~T}_{3}\right)$ & $60\left(\mathrm{~T}_{4}\right)$ \\
\hline \multirow{2}{*}{ Dega $\left(\mathrm{V}_{1}\right)$} & $1.06 \mathrm{~b}$ & $0.85 \mathrm{~b}$ & $0.83 \mathrm{a}$ & $1.26 \mathrm{a}$ & $0.00 \mathrm{~b}$ \\
& $(\mathrm{a})$ & $(\mathrm{a})$ & $(\mathrm{a})$ & $(\mathrm{a})$ & $(\mathrm{b})$ \\
Deja $\left(\mathrm{V}_{2}\right)$ & $1.58 \mathrm{a}$ & $1.59 \mathrm{a}$ & $1.05 \mathrm{a}$ & $1.14 \mathrm{a}$ & $0.91 \mathrm{a}$ \\
& $(\mathrm{ab})$ & $(\mathrm{a})$ & $(\mathrm{c})$ & $(\mathrm{bc})$ & $(\mathrm{c})$ \\
\hline
\end{tabular}

Keterangan: Nilai tengah diikuti huruf yang sama tidak berbeda berdasarkan uji BNT pada taraf 5\%. Huruf dalam kurung dibaca arah horizontal, membandingkan antara Waktu Pengusangan pada varietas yang sama. Huruf kecil tanpa kurung dibaca arah vertikal, membandingkan antara varietas pada waktu pengusangan yang sama. 
Deja memiliki mekanisme untuk menekan laju respirasi saat benih diberi perlakuan etanol $20 \%$ selama 60 menit, sehingga viabilitas dan vigor benih varietas Deja dapat dipertahankan lebih lama. Hasil penelitian Zanzibar (2007) menunjukkan bahwa perlakuan uap etanol berpengaruh terhadap penurunan kualitas fisiologi pada benih mindi dan merba. Hal ini juga sejalan dengan hasil penelitian Handayani et al., (2014) yang menyatakan bahwa interaksi konsentrasi etanol dan lama deraan berpengaruh nyata terhadap panjang akar primer.

Ketika cadangan makanan pada kotiledon sudah habis digunakan oleh embrio, epikotil akan memunculkan daun baru agar tanaman dapat melakukan fotosintesis. Proses fotosintesis tersebut akan menghasilkan fotosintat yang dapat diukur laju asumilasinya (Campbell et al., 2000). Laju asimilasi bersih merupakan fotosintat bersih yang diakumulasikan dalam organ-organ simpanan (sink) atau dengan kata lain laju asimilasi bersih merupakan selisih asimilat atau fotosintat total yang dihasilkan dalam proses fotosintesis yang telah digunakan untuk menyusun organ-organ baru dan proses respirasi (Sumadi, et al., 2016). Laju asimilasi diukurketika tanaman kedelai berumur 21 hari setelah semai. Hasil analisis uji lanjut pada Tabel 7 menunjukkan bahwa laju asimilasi varietas Deja menurun seiring meningkatnya waktu pengusangan benih yang diberikan. Laju asimilasi varietas Deja lebih tinggi dibandingkan dengan varietas Dega pada setiap waktu pengusangan $0,15,30,45$, atau 60 menit. Di samping itu, varietas Deja masih mampu tumbuh dan menghasilkan fotosintat pada waktu pengusangan 60 menit, sedangkan varietas Dega tidak. Hal ini ditunjukkan dengan nilai laju asimilasi varietas Deja pada waktu pengusangan 60 menit sebesar $0.91 \mathrm{~mol} \mathrm{~m}^{-2} \mathrm{~s}^{-1}$. Dengan demikian, varietas Deja diduga memiliki efisiensi dalam pemanfaatan asimilat dibandingkan dengan varietas Dega.

\section{KESIMPULAN}

Berdasarkan penelitian yang telah dilakukan dapat disimpulkan bahwa (1) viabilitas benih kedelai menurun pada waktu pengusangan 15 menit (2) varietas Deja memiliki viabilitas dan vigor benih lebih tinggi dibandingkan dengan varietas Dega yang ditunjukkan pada peubah persentase daya tumbuh, jumlah daun, panjang akar primer dan laju asimilasi yang lebih tinggi.

\section{UCAPAN TERIMA KASIH}

Terimakasih diucapkan kedapa Politeknik Negeri Lampung yang telah mendanai penelitian ini melalui Hibah DIPAPoliteknik Negeri Lampung Skema Penelitian Ilmu Pertanian.

\section{DAFTAR PUSTAKA}

[BPS] Badan Pusat Statistik. 2020. Impor Kedelai Menurut Negara Asal Utama, 2010-2019. RetrievedApril 20, 2021, from www.bps.go.id

Addai L.K. dan O.S. Kantanka. 2006. Evaluation of screening methods for improved storability of soybean seed. International Journal of Botany. 2(2): 152-155.

Afriansyah, M. Ermawati, E. Pranomo, dan Y. Nurmiaty. 2021. Viabilitas benih dan vigor kecambah empat genotipe sorgum (Sorghum bicolor [L.] Moench) pasca penyimpanan 16 bulan. J. Agrotek Tropika. 9(1): 129-136. 
Anggraeni, N.D. dan F.C. Suwarno. (2014). Kemampuan benih kedelai (Glycine max L.) untuk mempertahankan viabilitasnya setelah didera dengan etanol. Bul.Agrohorti. 1(4): 34-44.

Campbell, N.A., J.B. Reece, dan L.G. Mitchell. 2000. Biologi. Edisi kedua Jilid 2. Jakarta: Erlangga.

Copeland, L.O. dan M. B. McDonald. 2001. Principles of Seed Science and Technology (4th Edition). London (USA): Kluwer Academic Publishers.

Handayani, M.D.A., E. Pramono, dan M.S. Hadi. 2014. Pengaruh konsentrasi etanol dan lama deraan pada viabilitas benih buncis (Phaseolus vulgaris L.). J. Agrotek Tropika. 2(1): 83-88.

Justice, O.L. dan L.N. Bass. 2002. Prinsip dan Praktek Penyimpanan Benih. Rennie R, penerjemah. Terjemah dari: Principles and Practices of Seed Storage. Jakarta: Raja Grafindo.

Manurung, R.M.H. 2002. Tantangan dan peluang pengembangan tanaman kacang-kacangan dan umbi-umbian. Malang. Balai Penelitian Tanaman Kacang-Kacangan dan UmbiUmbian. 19-40.

Mustika, S., M.R. Suhartono, dan A. Qadir. 2014. Kemunduran benih kedelai akibat pengusangan cepat menggunakan alat IPB 77-1 MM dan penyimpanan alami. Bul. Agrohorti. 2(1): 1-10.

Nizaruddin, F.C. Suwarno, E. Widajati, dan A. Qadir. 2013. Metode deteriorasi terkontrol untuk pendugaan daya simpan benih kedelai. $J$. Agron. Indonesia. 42(1): 24-31.
Ozouline, M., N. Tahani., C. Demandre., and A.E. Amrani. 2009. Effect of accelerated ageing upon the lipid composition of seeds from two soft wheat varieties from marocco. Grasas $Y$ Aceites. 60(4): 367-374.

Rosida, A., M. Sari, A. Qadir. 2015. Pendugaan vigor daya simpan benih kubis (Brassica oleracea L. var. capitata) menggunakan metode pengusangan cepat dengan etanol. J. Hort. Indonesia. 6(3), 152-160.

Sadjad, S. 1980. Panduan Mutu Benih Tanaman Kehutanan di Indonesia. Bogor: Institut Pertanian Bogor.

Sumadi, P. Suryatmana, dan D. Sobardini. 2016. Pengaruh aplikasi pelapisan benih terhadap viabilitas benih terdeteriorasi serta pertumbuhan tanaman kedelai. Jurnal Kultivasi. 15(2): 107-113.

Tatipata A, P. Yudono, A. Purwantoro, dan W. Mangoendidjojo. 2004. Kajian aspek fisiologi dan biokimia deteriorasi benih kedelai dalam penyimpanan. JIPI. 11(2):7687.

Tatipata, A. 2008. Pengaruh kadar air awal, kemasan dan lama simpan terhadap protein membran dalam mitokondria benih kedelai. Bul. Agron. 36(1): 8-16.

Zanzibar, M. dan N. Herdiana. 2007. Pengaruh perlakuan pengusangan dengan uap etanol terhadap penurunan kualitas fisiologi benih akor, merbau dan mindi. J. Penelitian Hutan Tanaman. (4): 069-118. 